\title{
Alzheimer's disease: risk factors and potentially protective measures
}

\author{
Marcos Vinícius Ferreira Silva ${ }^{1 *}$, Cristina de Mello Gomide Loures ${ }^{1}$, Luan Carlos Vieira Alves ${ }^{1}$, \\ Leonardo Cruz de Souza ${ }^{2}$, Karina Braga Gomes Borges ${ }^{1}$ and Maria das Graças Carvalho ${ }^{1}$
}

\begin{abstract}
Alzheimer's disease (AD) is the most common type of dementia and typically manifests through a progressive loss of episodic memory and cognitive function, subsequently causing language and visuospatial skills deficiencies, which are often accompanied by behavioral disorders such as apathy, aggressiveness and depression. The presence of extracellular plaques of insoluble $\beta$-amyloid peptide (A $\beta$ ) and neurofibrillary tangles (NFT) containing hyperphosphorylated tau protein (P-tau) in the neuronal cytoplasm is a remarkable pathophysiological cause in patients' brains. Approximately $70 \%$ of the risk of developing AD can be attributed to genetics. However, acquired factors such as cerebrovascular diseases, diabetes, hypertension, obesity and dyslipidemia increase the risk of $A D$ development. The aim of the present minireview was to summarize the pathophysiological mechanism and the main risk factors for AD. As a complement, some protective factors associated with a lower risk of disease incidence, such as cognitive reserve, physical activity and diet will also be addressed.
\end{abstract}

Keywords: Alzheimer's disease, Genetic risk factors, Acquired risk factors

\section{Introduction}

Alzheimer's disease (AD) is the most common type of dementia [1], affecting at least 27 million people and corresponding from 60 to $70 \%$ of all dementias cases [2]. The occurrence of this disease also has a huge impact on life of patient's family, in addition to a high financial cost to society [3]. From an anatomopathological point of view, $\mathrm{AD}$ is characterized by two prototypical lesions: 1) senile plaques, composed of a nucleus of $\beta$-amyloid protein accumulation (A $\beta 42)$, as extra-cellular lesions and 2) neurofibrillary tangles composed of phosphorylated tau protein (P-tau) and which are intraneuronal findings [4]. Deposition of $\beta$-amyloid protein can also occur in capillaries walls, arteries and arterioles causing amyloid cerebral angiopathy leading to degeneration of vascular wall componentes and worsening of blood flow, besides predisposing to intraparenchymal hemorrhages [5].

\footnotetext{
* Correspondence: marcosvfs02@yahoo.com.br

${ }^{1}$ Faculdade de Farmácia, Universidade Federal de Minas Gerais, Avenida Presidente Antônio Carlos, 6627 - Pampulha, Belo Horizonte, Minas Gerais 31270-901, Brazil

Full list of author information is available at the end of the article
}

AD typically manifests through a progressive loss of episodic memory and cognitive function, with later deficiency of language and visuospatial abilities. Such changes are often accompanied by behavioral disorders such as apathy, aggressiveness and depression [6]. It should be noted that there is an important subgroup of $\mathrm{AD}$ patients who do not present a typically amnestic picture, manifesting non-amnestic deficits from the onset of symptoms [7]. Structural neuroimaging, with a pattern of hippocampal and parietal atrophy in typical cases reinforces the diagnosis [8]. Patients who meet typical disease characteristics, excluding other causes such as vascular and fronto-temporal dementias, have a probable diagnosis of AD [6]. Definitive diagnosis of the disease is usually carried out only through postmortem examination, whose purpose is to demonstrate histologically the neurofibrillary tangles and the senile plaques [9].

\section{Pathophysiology of Alzheimer's disease}

The presence of extracellular plaques of insoluble $\beta$-amyloid peptide $(\mathrm{A} \beta)$ and neurofibrillary tangles (NFT) of P-tau in neuronal cytoplasm is the hallmark of $\mathrm{AD}$ [10]. Although the mechanisms by which these changes lead to cognitive decline are still debated, these 
deposits are believed to lead to atrophy and death of neurons resulting from excitotoxicity processes [excessive stimulation of neurotransmitter receptors in neuronal membranes], collapse in calcium homeostasis, inflammation and depletion of energy and neuronal factors. As a result of this process, damage to neurons and synapses involved in memory processes, learning and other cognitive functions lead to the aforementioned cognitive decline [11].

According to amyloid cascade theory (one of the most accepted theories about AD pathogenesis, although still debated), the cerebral accumulation of $A \beta$ peptide, resulting from the imbalance between production and clearance of this protein, is the main event causing the disease, being other events observed (including the formation of NFT) resulting from this process [12].

The $A \beta$ peptide, which has 36 to 43 aminoacids, is derived from amyloid precursor protein (APP) enzymatic proteolysis, a physiologically produced protein that plays important roles in brain homeostasis $[13,14]$. The APP gene is located on chromosome 21, which explains the higher incidence of early-onset AD in individuals with 21 trisomy (Down Syndrome) and in individuals with $A P P$ gene locus duplication [a rare form of early onset of familial origin]. It is believed that overexpression of APP results in an increase of cerebral $A \beta$ peptide, and consequently, in its deposition [15].

Two main pathways for APP processing are now recognized: a non-amyloidogenic $\alpha$-secretase-mediated pathway and an amyloidogenic $\beta$-and $\gamma$-secretase-mediated pathway. Cleavage of APP by $\alpha$-secretase results in a soluble molecule, sAPP $\alpha$, which has probable neuroprotective function, playing important roles in the plasticity and survival of neurons and protection against excitotoxicity $[16,17]$. The $A \beta$ peptide is produced by APP cleavage by a $\beta$-secretase (mainly BACE1 enzyme). In this pathway, APP is cleaved by $\beta$-secretase to give a APP soluble fragment (SAPP $\beta$, a mediator related to neuronal death), and a carboxy-terminal complex linked to cell membrane. The latter is cleaved by a $\gamma$-secretase complex composed by 4 proteins: presenilin 1 or 2 , nicastrin, APH-1 (formerly pharynx-defective-1) and and PEN-2 (presenilin enhancer-2), to give rise to the $A \beta$ peptide. $A \beta$ peptides ranging in size from 38 to 43 aminoacids are generated with predominance of the 40 aminoacid form (A $\beta$ 40), followed by 42 (A $\beta 42)$ [17, 18]. In physiological conditions, the amyloidogenic and non-amyloidogenic pathways coexist in equilibrium, the latter being favored preferentially [19].

The $A \beta 42$ peptide is more prone to aggregation than $A \beta 40$. Immunohistochemical analyses indicate that $A \beta 42$ is initially deposited and found at higher concentrations in the amyloid plaques observed in $\mathrm{AD}$ patients [20]. Several studies showed that CSF A $\beta 42$ levels are surrogate markers of underlying brain amyloidosis $[21,22]$. On the contrary, the correlation between serum $A \beta 42$ levels and cerebral amyloidosis is not yet demonstrated. A decrease in A $\beta 42$ levels is observed in cerebrospinal fluid of $\mathrm{AD}$ subjects, which can be explained in part by higher deposition of $\beta$-amyloid plaques [23]. As additional evidence of $A \beta 42$ peptide and the $\mathrm{AD}$ pathophysiology, it is further noted that mutations in APP and presenilin genes, which give rise to early-onset familial $\mathrm{AD}$ forms, lead to a relative increase in $A \beta 42$ levels [20].

$\mathrm{A} \beta$ peptides, under physiological conditions, are produced primarily in monomeric forms with synapses protective function. However, the accumulation of this protein leads to formation of fibrils that accumulate in senile plaques. High levels of $A \beta$ may lead to oligomeric products formation (dimers, trimers, tetramers) leading to neuronal toxicity and degeneration (both by interaction with cell membranes and their receptors, and by direct interference in intracellular processes), interfering with the function and survival of cholinergic, serotonergic, noradrenergic and dopaminergic neurons, reducing their control over the amyloidogenic pathway and favoring the accumulation of insoluble $A \beta$ peptide $[19,24]$.

The exact mechanism by which deposition of $A \beta$ peptide promotes NFT formation of hyperphosphorylated tau protein is not known. Blurton-Jones \& Laferla (2006) [25] suggest four basic mechanisms:

a. The $A \beta$ peptide promotes the activation of specific kinases (GSK3 $\beta$, e.g.) that catalyze the hyperphosphorylation of tau protein, leading to its conformation change and formation of NFT;

b. Neuroinflammation promoted by the deposition of $A \beta$ peptide leads to the production of proinflammatory cytokines that stimulate the phosphorylation of tau protein;

c. Reduced capacity of degradation of tau protein by the proteasome, in a process induced by $\mathrm{A} \beta$ peptide;

d. Defects in axonal transport promoted by $A \beta$ peptide lead to inadequate localization of tau protein and its messenger RNA, which can lead to hyperphosphorylation and aggregation in NFT.

Tau protein is a microtubule-associated protein, produced by alternative splicing of the MAPT gene, located on chromosome 17 (17q21). Six isoforms of tau protein are produced by this process [26]. The main known physiological functions of this protein are the stimulation of tubulin polymerization, microtubules stabilization and intracellular organelles transport by microtubules. Once hyperphosphorylated, the protein loses its functions in the synthesis and stabilization of microtubules, leading to 
neuronal damage and promoting cytotoxicity [27]. Histological analyses demonstrate that both the load and the distribution of NFT in brain tissue correlate better with the severity of cognitive deficit than the $A \beta$ peptide deposits [28].

\section{Genetic risk factors}

$\mathrm{AD}$ can be classified by the age of onset of the first symptoms. Early-onset AD affects individuals under 65 years of age, accounting for about 4-6\% of cases of AD, while the late form $\mathrm{AD}$ affects individuals aged 65 years or older. Besides the age of onset of symptoms, the early and late forms of $\mathrm{AD}$ differ in other clinical, neuropsychological, neuropathological and neuroimaging variables [29].

According to Ballard et al. (2011) [1] about $70 \%$ of the risk of developing $\mathrm{AD}$ can be attributed to genetics. Early AD usually occurs due to mutations in genes APP, PSEN1 and PSEN2 (genes of amyloid precursor protein, presenilin 1 and presenilin 2, respectively), whereas late-form $\mathrm{AD}$ is mainly associated with a polymorphism in $A P O E$ gene (apolipoprotein $\mathrm{E}$ gene), especially the presence of $\varepsilon 4$ allele [30, 31].

More than 30 dominant mutations have already been found in APP gene (located in chromosome 21q21) and are associated with about $15 \%$ of cases of early-onset autosomal dominant AD. Mutations in PSEN1 gene (located at $14 \mathrm{q} 24.3$ ) are associated with $80 \%$ of cases of early-onset $\mathrm{AD}$, whereas $5 \%$ of cases are associated with PSEN2 mutations (located at 1q31-q42) [32]. Most of $A P P$ gene mutations, as well as PSEN1 mutations, lead to an increase in $A \beta 42: A \beta 40$ ratio, either by $A \beta 42$ increased expression, reduction of $A \beta 40$, or both. This deregulation favors early $A \beta$ deposition in brain tissue favoring the amyloidogenic cascade [33]. It is believed that there are other genes besides APP, PSEN1 and PSEN2 involved in the pathogenesis of early-onset AD, as demonstrated by Campion et al. (1999) [34].

Apolipoprotein E (ApoE) is a protein involved in lipid metabolism encoded by $A P O E$ gene, located on chromosome 19. There are three APOE alleles described $(\varepsilon 2, \varepsilon 3$ and $\varepsilon 4$, giving rise to apoE2, apoE3 and apoE4 isoforms), present in population at different frequencies $(\varepsilon 2: 5-10 \%$, $\varepsilon 3: 65-70 \%$ and $\varepsilon 4: 15-20 \%)$. A study by Corbo and Scacchi (1999) [35] showed that there is a great variability in the APOE allele distribution among the different populations, with $\varepsilon 2$ frequencies varying from 0.0 in some Native American populations up to 0.145 in Papuans. The $\varepsilon$ 4 frequencies obtained by the authors range from 0.052 (Sardinians) to 0.407 (Pygmies). The $\varepsilon 4$ allele is the main risk factor for late-onset AD. The presence of $\varepsilon 4$ in heterozygosity increases 3-fold the risk of $\mathrm{AD}$ developing, whereas in homozygosis, the risk is increased 12-fold. Conversely, the presence of $\varepsilon 2$ allele reduces the risk of $\mathrm{AD}$ developing [36, 37].
The causes of the association between apoE are not yet fully understood, although some mechanisms have been proposed, and presented consistent results in clinical and in vitro studies. Among these studies, some show that apoE is able to bind to $A \beta$ peptide. While the apoE4 isoform binds to $A \beta$ peptide promoting its polymerization in fibrils and its deposition, apoE2 and apoE3 forms are more efficient in promoting the clearance of this peptide, reducing its deposition in brain tissue [38]. ApoE has neuroprotective effects and is able to act on neurons development, with apoE2 and apoE3 performing better than apoE4. Additionally, it is observed that protease-generated apoE fragments have toxic effects, which may lead to neuronal injury and favor $A \beta$ peptide deposition [38, 39].

More recently it was observed that rare alterations in the triggering receptor expressed on myeloid cells 2 (TREM2) gene elevated the risk ratio by $2.9 \%$ for $\mathrm{AD}$ development $[40,41]$. The pathophysiological mechanism by which the deficiency in the gene increases the risk ratio for $\mathrm{AD}$ still needs to be better clarified. The gene is located on chromosome 6p21 [42] and the TREM2 protein is a highly expressed receptor on the surface of microglia, phagocytic cells of central nervous system, and has the function of modulating phagocytic and inflammatory responses in central nervous system [43]. Activation of microglia through the interaction of TREM2 and DAP12 stimulates the production of CCL19 and CCL21 chemokines and phagocytosis [44]. In knockout models for the TREM2 receptor it was observed that phagocytic capacity of apoptotic neuronal cell bodies was deficient [44]. Thus the accumulation of these cellular debris would promote a proinflammatory microenvironment [44]. Xiang et al. (2016) [45] observed that the removal capacity of $A \beta$ peptide deposits is impaired in TREM2 receptor deficiency and would favor amyloid plaques accumulation.

\section{Acquired risk factors}

A number of acquired factors increase the risk of developing AD. Among those factors are cerebrovascular diseases (most commonly reported risk factor), diabetes, hypertension, obesity and dyslipidemia [46]. The association of these risk factors to AD development will be described in the following subsections, as well as some protective factors associated with a lower risk of disease incidence, such as cognitive reserve, physical activity and diet as reported by Mayeux \& Stern (2012) [46].

\section{Cerebrovascular diseases}

Cerebrovascular diseases and $\mathrm{AD}$ share many risk factors, which often overlap. Cerebrovascular changes such as hemorrhagic infarcts, small and large ischemic cortical infarcts, vasculopathies, and changes in cerebral 
white matter are known to increase the risk of dementia. Postmortem analyses of the brains of patients with $\mathrm{AD}$ indicate the presence of parenchymal vascular disease (amyloid angiopathy by $\mathrm{A} \beta$ peptide and small vessels arteriolosclerotic disease), with hemorrhagic outbreaks and infarcts being found in more than $50 \%$ of them [47, 48]. According to Liu et al., (2015) [49], neuropathological findings indicate that between 6 and 47\% of individuals with dementia have a simultaneous occurrence of cerebrovascular disease. These observations point to the potential role of homeostatic mechanisms in AD and lead to question whether the dementias in which vascular processes are involved are fundamentally different from those related to accumulation of $A \beta 42$ and tau proteins or if both pathological processes produce synergistic effects on cognitive function [9].

According to the "double-stroke" theory of AD, vascular risk factors ("first stroke") lead to dysfunction in blood-brain barrier and reduction in cerebral blood flow, with decreased blood supply to the region (oligoemia). This event leads to neuronal damage by non-amyloidogenic and amyloidogenic pathways. Firstly, the dysfunction of blood-brain barrier leads to oligoemia and the accumulation of neurotoxic molecules, events associated with the occurrence of multiple focal ischemic infarcts and micro-injuries resulting from hypoxia, causing neuronal damage. In the amyloidogenic pathway, vascular injury leads to increased expression and processing of APP, resulting in an increase in $A \beta$ peptide. In addition, damage to blood-brain barrier leads to decreased clearance of $A \beta$ peptide. The accumulation of amyloid in brain ("second stroke") amplifies neuronal dysfunction and speeds up neurodegeneration process. Both $A \beta$ peptide accumulation and hypoperfusion lead to hyperphosphorylation of tau protein, promoting the formation of NFT [50].

\section{Hypertension}

A longitudinal study carried out by Skoog et al. (1996) demonstrated that hypertension is capable of leading to increased risk of developing AD [51]. Other studies have confirmed this association, indicating that hypertension, especially when present in middle age, negatively affects cognitive performance at more advanced ages, and this association becomes weaker with age [52]. Hypertension is capable of causing changes in the vascular walls which can lead to hypoperfusion, ischemia and cerebral hypoxia, contributing to trigger the development of $\mathrm{AD}$. Studies demonstrate that cerebral ischemia is capable of leading to the accumulation of APP and A $\beta$, in addition to stimulating the expression of presenilin, involved in A $\beta$ synthesis. Hypertension may also lead to dysfunction in the blood-brain barrier, an event associated with the genesis of AD by previously discussed mechanisms [53].

\section{Type 2 diabetes}

Epidemiological studies indicate a clear association between type 2 diabetes mellitus and the increased risk of developing AD. Several mechanisms for this association are suggested, including insulin resistance and insulin deficiency, impaired insulin receptor, toxicity of hyperglycemia, adverse effects due to advanced glycation end products, cerebrovascular damage, vascular inflammation and others [54].

The use of animal models was able to demonstrate that deficiency or resistance to insulin are able to stimulate the action of $\beta$ and $\gamma$-secretases, besides promoting reduction of $A \beta$ clearance, leading to its accumulation in brain tissue. Insulin resistance or deficiency are still capable of inducing hyperphosphorylation of tau protein, leading to NFT formation. Insulin and insulin-like growth factor bind to insulin receptor, leading to its autophosphorylation and activation. Activation of this receptor leads to phosphorylation of phosphoinositide 3-kinase (PI3K) enzyme, which in turn phosphorylates and inhibits glycogen synthase kinase $3 \beta$ (GSK3 $\beta$ ) enzyme, which is important for tau protein phosphorylation. Thus, insulin deficiency / resistance leads to GSK3 $\beta$ abnormal activation, and consequently, to an increase of p-tau formation [55].

In addition to the mechanisms discussed earlier, studies have reported that advanced glycation end products (AGEs) induce neuronal death through activation of cell death pathways, in addition to stimulating APP processing through increased expression of complexes $\beta$ and $\gamma$-secretases (BACE and PSEN1), in a process involving reactive oxygen species generation [56]. In addition, $A \beta$ peptide may undergo non-enzymatic glycation, making it an AGE more neurotoxic than its non-glycated form [57].

\section{Obesity}

The role of obesity as a risk factor for $\mathrm{AD}$ development is still uncertain, with studies presenting rather heterogeneous results. According to a meta-analysis developed by Profenno, Porsteinsson, \& Faraone (2010) [58], obesity (Body Mass Index - BMI $\geq 30 \mathrm{~kg} / \mathrm{m}^{2}$ ) is significantly and independently associated with $\mathrm{AD}$ developing risk. On the other hand, a meta-analysis conducted by Fitzpatrick et al. (2009) [59] indicated that obesity in middle age is a risk factor for dementia development (hazard ratio - HR: 1.39 ; 95\% CI: 1.03-1.87), while in later stages of life, obesity is inversely correlated with the risk of dementia (HR: 0.63; 95\% CI: 0.44-0.91). The same authors have also reported that below-ideal weight (BMI $<20 \mathrm{~kg} /$ $\mathrm{m}^{2}$ ) is also associated with an increased risk of dementia (HR: 1.62, 95\% CI: 1.02-2.64). Weight loss at more advanced ages occurs in concomitance to other comorbidities and is often indicative of poor health, and may even 
precede dementia onset within 10 years. Another metaanalysis conducted by Anstey et al. (2011) [60] indicated that both low weight and overweight as well as obesity in middle age are associated with a higher risk of developing $\mathrm{AD}$ in late life.

\section{Dyslipidemia}

Elevated cholesterol levels have been proposed as risk factors for the development of AD. Studies have already demonstrated $10 \%$ higher cholesterol levels in patients with $\mathrm{AD}$, compared to healthy individuals [61]. Hypercholesterolemia is a risk factor both for atherosclerosis development and AD development as well as other neurodegenerative diseases [62].

Hypercholesterolemia increases AD risk primarily because of its effects on the blood-brain barrier. Studies have shown that elevated circulating cholesterol levels are capable of compromising integrity in blood-brain barrier [62], resulting in mechanisms previously discussed. In addition, experimental studies using animal models demonstrate that hypercholesterolemia is associated with increased $A \beta$ peptide deposition, in addition to increased NFT formation, cognitive decline, neuroinflammation, dysfunction of cholinergic neurons and the presence of cerebral microhemorrhages compatible with AD $[63,64]$.

In observational studies a beneficial effect was observed in the users of statins as the reduction in $\mathrm{AD}$ incidence or improvement in the disease progression [65-67]. However, clinical studies to date have not demonstrated benefit of statins treatment and protection against cognitive decline in $\mathrm{AD}$ patients at various stages of disease [68-72]. Contrary to meta-analysis findings conducted by Song et al. (2013) [73] who observed a lower risk of developing $\mathrm{AD}$ in statins users, a Cochrane meta-analysis [74] did not observe difference in disease outcome as well as alteration in mini-mental status examination (MMSE) in patients using or not statins. However, some important questions regarding the clinical studies are pointed out, i.e., whether treatment initiated in middle age prior disease onset would also have a beneficial effect in elderly, or whether in people with $\mathrm{AD}$ family history the treatment would be effective in comparison to those without this background.

\section{Marital status, stress, depression and inadequate sleep}

Widowhood status has been reported as an important risk factor $\mathrm{AD}$. A cohort study by Håkansson et al. (2009) [75] shows that widowed individuals have an increased risk of developing $\mathrm{AD}$ compared to married or cohabiting individuals and that this effect is more pronounced in carriers of the APOE $\varepsilon 4$ allele. Other studies, such as that by Fan et al. (2015) [76] demonstrated an association between the risk of all-cause dementia and widow status. A meta-analysis by Sommerlad et al.
(2018) [77] reported an association between widowhood and all-cause dementia, but the same association was not found between widowhood and AD or vascular dementia.

Studies in animal models of $\mathrm{AD}$ have shown that stress, characterized as hyperactivation of the hypothalamic, pituitary and adrenal axis (HPA) leading to an increase in cortisol production, causes an increase in $A \beta$ peptide deposition in regions of the brain such as hypothalamus and prefrontal cortex [78-80]. Carroll et al. (2011) [81] have observed that the prolonged stress caused by this hyperactivation also causes an increase in the accumulation of hyperphosphorylated tau and neurodegeneration in mice. In humans, increased levels of cortisol were observed in patients with $\mathrm{AD}$ compared to the control group [82-84]. Huang et al. (2009) [85] observed in a 2-year follow-up of patients with AD that the higher cortisol levels correlated with the faster progression of the disease, worsened in the MMSE and smaller volume of the hippocampus region when observed by resonance. The authors of this study argue that hippocampal atrophy causes a disinhibition effect on the HPA axis, which would cause elevation in cortisol levels as a consequence of the pathophysiological process of $\mathrm{AD}$. Toledo et al. (2012) [86], observed in a sample of $26 \mathrm{pa-}$ tients with $\mathrm{AD}$ that the increase in cortisol levels is correlated with the deposition of the $A \beta$ peptide observed by means of pittsburgh compound b-positron emission tomography (PiB-PET). Ennis et al. (2017) [87], in a 10-year longitudinal study with 1025 participants observed an increased risk of 1.31 for the development of $\mathrm{AD}$ and elevation in cortisol levels that were dosed in 24-h urine samples. However, this result contrasts with that observed in the Rotterdan study [88] in blood samples collected in the morning when there was no correlation between cortisol levels and $\mathrm{AD}$ or dementia in general.

Early adult depression is a risk factor for the development of dementia at more advanced age including $\mathrm{AD}$ [89-91]. Zverova et al. (2013) [83] observed a greater odds ratio for cognitive decline in the presence of cortisol levels and patients with AD and symptoms of depression. Wu et al. (2018) [92] observed in some patients with major depression in middle age hippocampal atrophy and $A \beta$ peptide deposition observed by PET indicating that the protein metabolism may be altered in patients with depression.

According to a study published by Proserpio et al. (2018) [93], sleep disorders have a bidirectional relationship with AD: sleep disorders arise during the early stages of dementia and tend to worsen with the onset of dementia. Similarly, sleep disorders can lead to an increased risk of dementia. A meta-analysis by Shi et al. (2018) [94] demonstrated that individuals with sleep 
disorders have an increased risk of developing dementia. More specifically, individuals with insomnia are at high risk for developing AD but not for vascular dementia or other causes. Similarly, individuals with sleep disordered breathing had an increased risk of developing all-cause dementia, $\mathrm{AD}$, and vascular dementia.

\section{Smoking}

Smoking may affect the risk of developing AD by various mechanisms. It is known that it is able to raise the generation of free radicals, increasing oxidative stress, and to promote pro-inflammatory action in the immune system, leading to the activation of phagocytes and consequently, additional oxidative damage. In addition, smoking may lead to cerebrovascular diseases, which increase the risk of $\mathrm{AD}[95,96]$. In a meta-analysis performed by Cataldo et al. (2010), an analysis of 8 case-control studies with affiliations with the tobacco industry suggested a protective effect of smoking in relation to AD (odds ratio (OR): $0.91,95 \%$ CI $0.75-1,10$ ). In contrast, 14 cohort studies with no association with the tobacco industry demonstrated an increased relative risk for smokers (Relative Risk (RR): 1.45; 95\% CI, 1.161.80) [97]. According to Durazzo et al. (2014), the sum of the evidence presented today in the literature is enough for the cessation of smoking to be recommended in order to reduce the incidence of dementia [96].

\section{Protective factors}

\section{Cognitive reserve}

It has been observed in many cases a discrepancy between the degree of brain damage found in histopathological analyses and the severity of cognitive decline. To explain these findings, the theory of cognitive reserve was proposed, which postulates that the gap between brain injury and clinical manifestations is attributable to cognitive reserve capacity. This can be subdivided into two models: brain reserve model or threshold, and cognitive reserve model and / or compensation. The first is based on the amount of available neural substrate (eg, brain size, synapses density or dendritic branching), while the latter focuses on the more efficient ability to use the preexisting brain network in healthy individuals and on the recruitment of more resources to support normal functioning in presence of brain damage [98].

Several elements are associated with a greater cognitive reserve, such as educational level, occupational activities, leisure activities, physical activities and the integrity of relationships network $[98,99]$. A study conducted by Stern et al. (1994) [100] indicated that individuals with low level of schooling and low level of professional achievement had an approximately two-fold increased risk of developing dementia. Similarly, another study indicated that individuals with a higher level of leisure activities performance had a lower risk of developing dementia [101].

\section{Physical activity}

A meta-analysis developed by Hamer \& Chida (2009) [102] indicated that physical activity practice is able to reduce AD risk by $45 \%$. This protective effect is related to several mechanisms, such as reduction of blood pressure, obesity and proinflammatory activity besides the improvement in lipid profile and endothelial function. In addition, adaptations that occur in response to exercise can lead to a better cerebral blood flow and, consequently, better oxygenation of important areas for cognitive function [102]. It is also believed that physical activity is able to prevent $\mathrm{AD}$ by increasing neurotrophic factors such as BDNF (Brain Derived Neurotrophic Factor), IGF-1 (Insulin-Like Growth Factor), VEGF (Vascular Endothelial Growth Factor), stimulating neurogenesis and synaptic plasticity; and by the reduction of free radicals in the hippocampus, as well as increase of superoxide dismutase and eNOS (endothelial nitric oxide synthase) [103]. Studies have shown that the practice of physical activities is capable of promoting an increase in hippocampal volume, in addition to increasing plasma BDNF concentrations in healthy elderly, indicating a possible neuroprotective effect. It was also reported that in the AD elderly, practice of physical activities correlates positively with the levels of BDNF [104], which is a growth factor associated with the development and survival of neurons and synapses [105].

\section{Diet}

The relationship between the effects of diet and the risk of developing $\mathrm{AD}$ was based on certain patterns that were associated with lower or higher risk of developing $\mathrm{AD}$ [106]. As an example, Mediterranean diet is rich in unsaturated fats and antioxidants which confers a protection factor, as diets rich in saturated and trans fats and low levels of anti-oxidants are associated with higher risk of developing AD [106, 107]. Some dietary components are essential for neurocognition protection such as dietary fatty acids, including fish oil; antioxidants, such as vitamins $E$ and $C$; fruits and vegetables; vitamins B6, B12 (cobalamine) and folate, in addition to caloric restriction [108]. Antioxidants are able to prevent damage caused by reactive oxygen species in addition to stabilizing the membranes; docosahexaenoic acid (DHA) helps clear the $A \beta$ peptide and, together with choline and uridine, aid in the synthesis of the neuronal membrane [106]. Phospholipid composition is essential in neuronal membrane function. Thus, adequate intake of DHA, eicosapentaenoic acid (EPA), uridine monophosphate, choline, folate, vitamins B6, B12, C, and E, and selenium contributes to a better synthesis of phospholipids 
and, consequently, to synaptic function preservation and against neurodegeneration [106]. Nerve synapses consist mainly of neuronal membranes, and neuronal and synaptic losses observed in AD have been related to degeneration and alteration in the composition of these membranes [109]. Brain aging associated with changes in lipid composition is well studied for treatment and prevention purposes with phospholipids such as phosphatidylcholine and phosphatidylserine that could favor cognitive improvement [110]. The OmegAD study (a set of double-blind, placebo-controlled clinical trials involving AD patients which evaluated the effects of omega- 3 fatty acids ( $\mathrm{n}-3$ FAs) daily supplementation in patients with mild to moderate AD) showed that after six months, DHA (1.7 g) and EPA (0.6 g) supplementation demonstrated benefits such as preservation of cognitive performance, increase in plasma and CSF (Cerebrospinal fluid) levels of $\mathrm{n}^{-3}$ FAs, DHA and EPA (and negative correlation between DHA and total / phosphorylated tau levels in CSF), reduction in cytokine release pro-inflammatory by blood peripheral mononuclear cells (PBMC), modulation in the expression of genes involved in the regulation of inflammation in PBMC, elevation in transthyretin plasma levels (a protein that binds to $A B$ and which may influence its deposition in the brain), and increase in body weight and BMI. However, the literature data do not support the benefits of 3-FA supplementation in preventing cognitive decline in elderly subjects [111].

\section{Vitamin D}

Epidemiological studies have observed a relationship between serum levels of vitamin D reduction, especially 25-hydroxyvitamin D, and AD development [112-114]. Vitamin D is an important steroid hormone that acts on calcium metabolism and bone regulation, and has some functions in central nervous system, such as regulation of neurotrophic factors, calcium homeostasis, acts on oxidative stress mechanisms, immune system modulation and inflammation [115]. In the case of inflammation, vitamin $\mathrm{D}$ deficiency causes an increase in the amyloidogenic pathway due to elevation of BACE1 and $A P P$ cleavage and decrease of $\mathrm{A} \beta$ degradation [116]. Briones \& Darwish (2012) [117] reported a BACE1 and $A \beta$ peptide reduction after vitamin $D$ supplementation in elderly rats. It has also been observed that vitamin $\mathrm{D}$ acts on macrophages in order to promote clearence of $\mathrm{A} \beta$ peptide $[118,119]$. In $\mathrm{AD}$ patients mutations were also observed in vitamin $\mathrm{D}$ receptor (VDR) gene, which would favor the onset of the disease [120]. To date, no large randomized clinical trial has been conducted on the effect of vitamin D supplementation on the cognition of AD patients. However, in smaller or cohort studies, the results of using high doses of vitamin $D$ and cognitive improvement are divergent [121-124]. Vitamin
$\mathrm{D}$ deficiency should be screened and supplemented in the elderly population due to its high prevalence, but this treatment is not specific for cognitive improvement.

\section{Estrogen (hormone replacement therapy)}

Estrogen roles in sex organs are well understood, but it has recently been observed that local production of estrogen plays specific roles in tissues in which it is produced, with or without dependence on circulating estrogen [125]. Estrogen, especially estradiol, is able to prevent mitochondrial dysfunction in nerve cells, neuroinflammation and assist in DNA repair mechanisms [126], thus presenting neuroprotective effect [126, 127]. The results observed in epidemiological studies are inconsistent $[128,129]$. Some studies have not observed a beneficial effect of hormone replacement therapy, estrogen or combination therapy on the risk of developing AD [130, 131]. Other studies reported a beneficial effect on cognition protection in women receiving hormone replacement therapy at different ages after the onset of menopause [132-135]. Inconsistent epidemiological findings, in addition to other factors such as increased risk of deep venous thrombosis, hormone replacement therapy is not recommended in order to prevent cognitive decline and AD development [136].

\section{Other relevant factors and conclusion}

The main pathophysiological mechanisms of AD are amyloidosis and tau-related neurodegeneration, and have specific topographical and chronological pathways. For instance, brain amyloidosis starts in neocortical regions and then affects subcortical structures [137]. On the other hand, neurodegeneration first appear on locus coeruleus and then spreads through transentorrinal area and neocortical regions [137]. Cognitive and behavioral features of $\mathrm{AD}$ are significantly correlated to the topographical distribution of neurofibrillary tangles.

There is great variability in topographical patterns of pathological findings in $\mathrm{AD}$, causing great phenotypical variability [7], with atypical presentations of the disease [138]. It is not clear how risk and beneficial factors may modulate the topographical progression of amyloidosis and neurodegeneration.

The effects of modifiable risk factors on cross-sectional cognition have been the target of multiple WRAP (The Wisconsin Registry for Alzheimer's Prevention) investigations. This study has investigated risk factors for $\mathrm{AD}$ in middle age, since this phase of life is less studied in relation to the later stages of aging. However, this is a critical time because it is when the Alzheimer's pathology begins and thus, when its trajectory can be modified through pharmacological approaches and / or lifestyle changes. Within this context, the WRAP study, reported by Johnson et al. (2018), suggest that social 
engagement, physical and cognitive activities, glucose regulation, stress and sleep, in addition to cardiovascular and metabolic risks are interventional parameters that may improve brain health and reduce the likelihood and severity of AD pathology. These authors conclude that a good health and a salutary lifestyle are factors associated not only with better cognition and brain structure but also the lower AD pathophysiologic burden [139].

The studies of genetic risk factors are important to better elucidate the pathophysiological processes in the development of AD. However, such factors are not passible to any intervention until now. Faced to this scenario, modifiable risk factors such as diabetes, hypertension and dyslipidemia and others previously mentioned should be closely monitored to prevent complications favoring cognitive decline or even to improve the quality of life of patients with AD. In this context, it should also be emphasized that factors considered protective, such as physical exercise, diet and cognitive stimuli should be strongly and widely encouraged, so that such theoretically preventive measures can be adopted by the population contributing to reduce risk of this disease. Since no current drug intervention can modify the pathophysiological mechanisms related to the development of this devastating disease, adoption of these measures constitutes an important strategy for clinical management in order to prevent or postpone cognitive decline.

\section{Abbreviations}

AD: Alzheimer's disease; AGEs: Advanced glycation end products; ApoE: Apolipoprotein E (ApoE); APP: Amyloid precursor protein; Aß: $\beta$-amyloid peptide; BDNF: Brain Derived Neurotrophic Factor; BMI: Body Mass Index; CSF: Cerebrospinal fluid; DHA: Docosahexaenoic acid; eNOS: Endothelial nitric oxide synthase; EPA: Eicosapentaenoic acid; HPA: Hypothalamic, pituitary and adrenal axis; HR: Hazard Ratio; IGF-1: Insulin-Like Growth Factor; n-3 FAs: Omega-3 fatty acids; NFT: Neurofibrillary tangles; PBMC: Peripheral blood mononuclear cells; P-tau: Phosphorylated tau protein; VDR: Vitamin D receptor; VEGF: Vascular Endothelial Growth Factor

\section{Acknowledgements}

Not applicable

\section{Funding}

CNPq, CAPES and Fapemig

\section{Availability of data and materials}

Not applicable

\section{Authors' contributions}

MVFS, CGML and LCVA drafted the manuscript. LCS, KBGB and MGC reviewed the manuscript. All authors read and approved the final manuscript.

\section{Ethics approval and consent to participate}

Not applicable

\section{Consent for publication}

Not applicable

\section{Competing interests}

The authors declare that they have no competing interests.

\section{Publisher's Note}

Springer Nature remains neutral with regard to jurisdictional claims in published maps and institutional affiliations.

\section{Author details}

${ }^{1}$ Faculdade de Farmácia, Universidade Federal de Minas Gerais, Avenida Presidente Antônio Carlos, 6627 - Pampulha, Belo Horizonte, Minas Gerais 31270-901, Brazil. ${ }^{2}$ Faculdade de Medicina, Universidade Federal de Minas Gerais, Av. Prof. Alfredo Balena, 190 - Santa Efigênia, Belo Horizonte, Minas Gerais 30130-100, Brazil.

Received: 19 January 2019 Accepted: 18 April 2019

Published online: 09 May 2019

\section{References}

1. Ballard C, Gauthier S, Corbett A, Brayne C, Aarsland D, Jones E. Alzheimer's disease. Lancet. 2011;377(9770):1019-31.

2. Ferreira D, Perestelo-Perez L, Westman E, Wahlund LO, Sarria A, SerranoAguilar P. Meta-review of CSF Core biomarkers in Alzheimer's disease: the state-of-the-art after the new revised diagnostic criteria. Front Aging Neurosci. 2014;6:47.

3. IDd A, FHdEdM G, Forlenza OV, UdS P, HLd B, et al. Alzheimer disease: correlation between memory and autonomy. Rev psiquiatr clín. 2005;32(3): 131-6.

4. Shinohara M, Sato N, Shimamura M, Kurinami H, Hamasaki T, Chatterjee A, et al. Possible modification of Alzheimer's disease by statins in midlife: interactions with genetic and non-genetic risk factors. Front Aging Neurosci. 2014;6:71.

5. Cortes-Canteli M, Paul J, Norris EH, Bronstein R, Ahn HJ, Zamolodchikov D, et al. Fibrinogen and beta-amyloid association alters thrombosis and fibrinolysis: a possible contributing factor to Alzheimer's disease. Neuron. 2010; 66(5):695-709.

6. Bateman RJ, Xiong C, Benzinger TLS, Fagan AM, Goate A, Fox NC, Marcus DS, Cairns NJ, Xie X, Blazey TM, Holtzman DM, Santacruz A, Buckles V, Oliver A, Moulder K, Aisen PS, Ghetti B, Klunk WE, McDade E, Martins RN, Masters CL, Mayeux R, Ringman JM, Rossor MN, Schofield PR, Sperling RA, Salloway S, Morris JC. Clinical and Biomarker Changes in Dominantly Inherited Alzheimer's Disease. N Engl J Med. 2012;367:795-804.

7. Murray ME, Graff-Radford NR, Ross OA, Petersen RC, Duara R, Dickson DW. Neuropathologically defined subtypes of Alzheimer's disease with distinct clinical characteristics: a retrospective study. Lancet Neurol. 2011;10(9):785-96.

8. de Souza LC, Sarazin M, Teixeira-Junior AL, Caramelli P, Santos AE, Dubois B. Biological markers of Alzheimer's disease. Arq Neuropsiquiatr. 2014;72(3): 227-31.

9. Kling MA, Trojanowski JQ, Wolk DA, Lee VM, Arnold SE. Vascular disease and dementias: paradigm shifts to drive research in new directions. Alzheimers Dement. 2013;9(1):76-92.

10. Kang $\mathrm{S}$, Lee $\mathrm{YH}$, Lee JE. Metabolism-centric overview of the pathogenesis of Alzheimer's disease. Yonsei Med J. 2017;58(3):479-88.

11. Mucke L. Neuroscience: Alzheimer's disease. Nature. 2009;461:895-7.

12. Hardy J, Selkoe DJ. The amyloid hypothesis of Alzheimer's disease: progress and problems on the road to therapeutics. Science. 2002;297(5580):353-6.

13. Querfurth HW, LaFerla FM. Alzheimer's disease. N Engl J Med. 2010;362(4): 329-44.

14. Muller UC, Deller T, Korte M. Not just amyloid: physiological functions of the amyloid precursor protein family. Nat Rev Neurosci. 2017;18(5):281-98.

15. Doran E, Keator D, Head E, Phelan MJ, Kim R, Totoiu M, et al. Down syndrome, partial trisomy 21, and absence of Alzheimer's disease: the role of APP. J Alzheimers Dis. 2017;56(2):459-70.

16. Gupta A, Goyal R. Amyloid beta plaque: a culprit for neurodegeneration. Acta Neurol Belg. 2016;116(4):445-50.

17. Zhang YW, Thompson R, Zhang H, Xu H. APP processing in Alzheimer's disease. Mol Brain. 2011;4:3.

18. Zhang H, Ma Q, Zhang YW, Xu H. Proteolytic processing of Alzheimer's beta-amyloid precursor protein. J Neurochem. 2012;120(Suppl 1):9-21.

19. Martorana A, Di Lorenzo F, Belli L, Sancesario G, Toniolo S, Sallustio F, et al. Cerebrospinal fluid Abeta42 levels: when physiological become pathological state. CNS Neurosci Ther. 2015;21(12):921-5.

20. Naslund J, Haroutunian V, Mohs R, Davis KL, Davies P, Greengard P, et al. Correlation between elevated levels of amyloid beta-peptide in the brain and cognitive decline. Jama. 2000;283(12):1571-7. 
21. Grimmer $T$, Riemenschneider M, Forstl H, Henriksen G, Klunk WE, Mathis CA, et al. Beta amyloid in Alzheimer's disease: increased deposition in brain is reflected in reduced concentration in cerebrospinal fluid. Biol Psychiatry. 2009;65(11):927-34.

22. Tapiola T, Alafuzoff I, Herukka SK, Parkkinen L, Hartikainen P, Soininen H, et al. Cerebrospinal fluid \{beta\}-amyloid 42 and tau proteins as biomarkers of Alzheimer-type pathologic changes in the brain. Arch Neurol. 2009;66(3): 382-9.

23. Blennow K, Hampel H. CSF markers for incipient Alzheimer's disease. Lancet Neurol. 2003;2(10):605-13.

24. Lee SJ, Nam E, Lee HJ, Savelieff MG, Lim MH. Towards an understanding of amyloid-beta oligomers: characterization, toxicity mechanisms, and inhibitors. Chem Soc Rev. 2017:46(2):310-23.

25. Blurton-Jones M, Laferla FM. Pathways by which Abeta facilitates tau pathology. Curr Alzheimer Res. 2006;3(5):437-48.

26. Kovacs GG. Invited review: neuropathology of tauopathies: principles and practice. Neuropathol Appl Neurobiol. 2015;41(1):3-23.

27. Khan SS, Bloom GS. Tau: the Center of a Signaling Nexus in Alzheimer's disease. Front Neurosci. 2016;10:31.

28. Nelson PT, Alafuzoff I, Bigio EH, Bouras C, Braak H, Cairns NJ, et al. Correlation of Alzheimer disease neuropathologic changes with cognitive status: a review of the literature. J Neuropathol Exp Neurol. 2012;71(5):362-81.

29. Mendez MF. Early-onset Alzheimer disease. Neurol Clin. 2017;35(2):263-81.

30. Giri M, Zhang M, Lu Y. Genes associated with Alzheimer's disease: an overview and current status. Clin Interv Aging. 2016;11:665-81.

31. Cacace $R$, Sleegers $K$, Van Broeckhoven C. Molecular genetics of early-onset Alzheimer's disease revisited. Alzheimers Dement. 2016;12(6):733-48.

32. Calero M, Gómez-Ramos A, Calero O, Soriano E, Avila J, Medina M. Additional mechanisms conferring genetic susceptibility to Alzheimer's disease. Front Cell Neurosci. 2015;9:138.

33. Bekris LM, Yu CE, Bird TD, Tsuang DW. Genetics of Alzheimer disease. J Geriatr Psychiatry Neurol. 2010;23(4):213-27.

34. Campion D, Dumanchin C, Hannequin D, Dubois B, Belliard S, Puel M, et al. Early-onset autosomal dominant Alzheimer disease: prevalence, genetic heterogeneity, and mutation spectrum. Am J Hum Genet. 1999;65:664-70.

35. Corbo RM, Scacchi R. Apolipoprotein E (APOE) allele distribution in the world. Is APOE*4 a 'thrifty' allele? Ann Hum Genet. 1999;63(Pt 4):301-10.

36. Karch CM, Goate AM. Alzheimer's disease risk genes and mechanisms of disease pathogenesis. Biol Psychiatry. 2015;77(1):43-51.

37. Mahley RW. Apolipoprotein E: from cardiovascular disease to neurodegenerative disorders. J Mol Med (Berl). 2016;94:739-46.

38. Kim J, Basak JM, Holtzman DM. The role of apolipoprotein E in Alzheimer's disease. Neuron. 2009;63(3):287-303.

39. Hauser PS, Narayanaswami V, Ryan RO. Apolipoprotein E: from lipid transport to neurobiology. Prog Lipid Res. 2011;50(1):62-74.

40. Jonsson T, Stefansson H, Steinberg S, Jonsdottir I, Jonsson PV, Snaedal J, et al. Variant of TREM2 associated with the risk of Alzheimer's disease. N Engl J Med. 2013;368(2):107-16

41. Guerreiro R, Wojtas A, Bras J, Carrasquillo M, Rogaeva E, Majounie E, et al. TREM2 variants in Alzheimer's disease. N Engl J Med. 2013;368(2):117-27.

42. Allcock RJ, Barrow AD, Forbes S, Beck S, Trowsdale J. The human TREM gene cluster at 6p21.1 encodes both activating and inhibitory single lgV domain receptors and includes NKp44. Eur J Immunol. 2003;33(2):567-77.

43. Jiang T, Zhang YD, Gao Q, Ou Z, Gong PY, Shi JQ, et al. TREM2 ameliorates neuronal tau pathology through suppression of microglial inflammatory response. Inflammation. 2018;41(3):811-23.

44. Mecca C, Giambanco I, Donato R, Arcuri C. Microglia and Aging: The Role of the TREM2-DAP12 and CX3CL1-CX3CR1 Axes. Int J Mol Sci. 2018;19(1):318.

45. Xiang X, Werner G, Bohrmann B, Liesz A, Mazaheri F, Capell A, et al. TREM2 deficiency reduces the efficacy of immunotherapeutic amyloid clearance. EMBO Mol Med. 2016;8:992-1004

46. Mayeux R, Stern Y. Epidemiology of Alzheimer Disease. Cold Spring Harb Perspect Med. 2012;2:a006239.

47. Reitz C, Brayne C, Mayeux R. Epidemiology of Alzheimer disease. Nat Rev Neurol. 2011;7(3):137-52

48. Love S, Miners JS. Cerebrovascular disease in ageing and Alzheimer's disease. Acta Neuropathol. 2016;131(5):645-58.

49. Liu W, Wong A, Law AC, Mok VC. Cerebrovascular disease, amyloid plaques, and dementia. Stroke. 2015;46(5):1402-7.

50. Zlokovic BV. Neurovascular pathways to neurodegeneration in Alzheimer's disease and other disorders. Nat Rev Neurosci. 2011;12(12):723-38.
51. Skoog I, Lernfelt B, Landahl S, Palmertz B, Andreasson LA, Nilsson L, et al. 15-year longitudinal study of blood pressure and dementia. Lancet. 1996;347(9009):1141-5.

52. Staessen JA, Richart T, Birkenhager WH. Less atherosclerosis and lower blood pressure for a meaningful life perspective with more brain. Hypertension. 2007; 49(3):389-400.

53. Skoog I, Gustafson D. Update on hypertension and Alzheimer's disease. Neurol Res. 2006;28(6):605-11.

54. Li X, Song D, Leng SX. Link between type 2 diabetes and Alzheimer's disease: from epidemiology to mechanism and treatment. Clin Interv Aging. 2015;10:549-60.

55. Kimura N. Diabetes mellitus induces Alzheimer's disease pathology: histopathological evidence from animal models. Int J Mol Sci. 2016;17(4):503.

56. Ko SY, Ko HA, Chu KH, Shieh TM, Chi TC, Chen HI, et al. The Possible Mechanism of Advanced Glycation End Products (AGEs) for Alzheimer's Disease. PLoS One. 2015;10.

57. Li XH, Du LL, Cheng XS, Jiang X, Zhang Y, Lv BL, et al. Glycation exacerbates the neuronal toxicity of beta-amyloid. Cell Death Dis. 2013;4:e673.

58. Profenno LA, Porsteinsson AP, Faraone SV. Meta-analysis of Alzheimer's disease risk with obesity, diabetes, and related disorders. Biol Psychiatry. 2010;67(6):505-12.

59. Fitzpatrick AL, Kuller LH, Lopez OL, Diehr P, O'Meara ES, Longstreth WT Jr, et al. Midlife and late-life obesity and the risk of dementia: cardiovascular health study. Arch Neurol. 2009;66(3):336-42.

60. Anstey KJ, Cherbuin N, Budge M, Young J. Body mass index in midlife and late-life as a risk factor for dementia: a meta-analysis of prospective studies. Obes Rev. 2011;12(5):e426-37.

61. Popp J, Meichsner S, Kolsch H, Lewczuk P, Maier W, Kornhuber J, et al. Cerebral and extracerebral cholesterol metabolism and CSF markers of Alzheimer's disease. Biochem Pharmacol. 2013;86(1):37-42.

62. Xue-shan Z, Juan P, Qi W, Zhong R, Li-hong P, Zhi-han T, et al. Imbalanced cholesterol metabolism in Alzheimer's disease. Clin Chim Acta. 2016:456:107-14.

63. Ricciarelli R, Canepa E, Marengo B, Marinari UM, Poli G, Pronzato MA, et al. Cholesterol and Alzheimer's disease: a still poorly understood correlation. IUBMB Life. 2012;64(12):931-5.

64. Ullrich C, Pirchl M, Humpel C. Hypercholesterolemia in rats impairs the cholinergic system and leads to memory deficits. Mol Cell Neurosci. 2010:45:408-17.

65. Hendrie HC, Hake A, Lane K, Purnell C, Unverzagt F, Smith-Gamble V, et al. Statin use, incident dementia and Alzheimer disease in elderly African Americans. Ethn Dis. 2015;25(3):345-54.

66. Haag MD, Hofman A, Koudstaal PJ, Stricker BH, Breteler MM. Statins are associated with a reduced risk of Alzheimer disease regardless of lipophilicity. The Rotterdam study. J Neurol Neurosurg Psychiatry. 2009; 80(1):13-7.

67. Lin FC, Chuang YS, Hsieh HM, Lee TC, Chiu KF, Liu CK, et al. Early statin use and the progression of Alzheimer disease: a Total population-based casecontrol study. Medicine (Baltimore). 2015;94(47):e2143.

68. Simons M, Schwarzler F, Lutjohann D, von Bergmann K, Beyreuther K, Dichgans J, et al. Treatment with simvastatin in normocholesterolemic patients with Alzheimer's disease: a 26-week randomized, placebocontrolled, double-blind trial. Ann Neurol. 2002;52(3):346-50.

69. Sano M, Bell KL, Galasko D, Galvin JE, Thomas RG, van Dyck CH, et al. A randomized, double-blind, placebo-controlled trial of simvastatin to treat Alzheimer disease. Neurology. 2011;77(6):556-63.

70. Feldman HH, Doody RS, Kivipelto M, Sparks DL, Waters DD, Jones RW, et al. Randomized controlled trial of atorvastatin in mild to moderate Alzheimer disease: LEADe. Neurology. 2010;74(12):956-64.

71. Shepherd J, Blauw GJ, Murphy MB, Bollen EL, Buckley BM, Cobbe SM, et al. Pravastatin in elderly individuals at risk of vascular disease (PROSPER): a randomised controlled trial. Lancet. 2002;360(9346):1623-30.

72. Heart Protection Study Collaborative Group. MRC/BHF Heart Protection Study of cholesterol lowering with simvastatin in 20,536 high-risk individuals: a randomised placebo-controlled trial. Lancet. 2002;360(9326):7-22.

73. Song $Y$, Nie $H, X u Y$, Zhang $L, W u Y$. Association of statin use with risk of dementia: a meta-analysis of prospective cohort studies. Geriatr Gerontol Int. 2013;13(4):817-24.

74. McGuinness B, Craig D, Bullock R, Passmore P. Statins for the prevention of dementia. Cochrane Database Syst Rev. 2016;(1):Cd003160. https://doi. org/10.1002/14651858.CD003160.pub3.

75. Håkansson K, Rovio S, Helkala EL, Vilska AR, Winblad B, Soininen H, et al. Association between mid-life marital status and cognitive function in later life: population based cohort study. BMJ. 2009;339:b2462 
76. Fan LY, Sun Y, Lee HJ, Yang SC, Chen TF, Lin KN, et al. Marital status, lifestyle and dementia: a Nationwide survey in Taiwan. PLoS One. 2015;10(9):e0139154.

77. Sommerlad A, Ruegger J, Singh-Manoux A, Lewis G, Livingston G. Marriage and risk of dementia: systematic review and meta-analysis of observational studies. J Neurol Neurosurg Psychiatry. 2018;89(3):231-8.

78. Ray B, Gaskins DL, Sajdyk TJ, Spence JP, Fitz SD, Shekhar A, et al. Restraint stress and repeated corticotrophin-releasing factor receptor activation in the amygdala both increase amyloid-beta precursor protein and amyloid-beta peptide but have divergent effects on brain-derived neurotrophic factor and pre-synaptic proteins in the prefrontal cortex of rats. Neuroscience. 2011;184:139-50.

79. Lesuis SL, Maurin H, Borghgraef P, Lucassen PJ, Van Leuven F, Krugers HJ. Positive and negative early life experiences differentially modulate long term survival and amyloid protein levels in a mouse model of Alzheimer's disease. Oncotarget. 2016;7(26):39118-35.

80. Justice NJ, Huang L, Tian JB, Cole A, Pruski M, Hunt AJ Jr, et al. Posttraumatic stress disorder-like induction elevates beta-amyloid levels, which directly activates corticotropin-releasing factor neurons to exacerbate stress responses. J Neurosci. 2015;35(6):2612-23.

81. Carroll JC, Iba M, Bangasser DA, Valentino RJ, James MJ, Brunden KR, et al. Chronic stress exacerbates tau pathology, neurodegeneration, and cognitive performance through a corticotropin-releasing factor receptor-dependent mechanism in a transgenic mouse model of tauopathy. J Neurosci. 2011; 31(40):14436-49.

82. Lara VP, Caramelli P, Teixeira AL, Barbosa MT, Carmona KC, Carvalho MG, et al. High cortisol levels are associated with cognitive impairment nodementia (CIND) and dementia. Clin Chim Acta. 2013;423:18-22.

83. Zverova M, Fisar Z, Jirak R, Kitzlerova E, Hroudova J, Raboch J. Plasma cortisol in Alzheimer's disease with or without depressive symptoms. Med Sci Monit. 2013;19:681-9.

84. Wang LY, Raskind MA, Wilkinson CW, Shofer JB, Sikkema C, Szot P, et al. Associations between CSF cortisol and CSF norepinephrine in cognitively normal controls and patients with amnestic $\mathrm{MCl}$ and $\mathrm{AD}$ dementia. Int J Geriatr Psychiatry. 2018;33(5):763-8.

85. Huang CW, Lui CC, Chang WN, Lu CH, Wang YL, Chang CC. Elevated basal cortisol level predicts lower hippocampal volume and cognitive decline in Alzheimer's disease. J Clin Neurosci. 2009;16(10):1283-6.

86. Toledo JB, Toledo E, Weiner MW, Jack CR, Jagust W, Lee VMY, et al. Cardiovascular risk factors, cortisol, and amyloid- $\beta$ deposition in Alzheimer's Disease Neuroimaging Initiative. Alzheimers Dement. 2012;8(6):483-9.

87. Ennis GE, An Y, Resnick SM, Ferrucci L, O'Brien RJ, Moffat SD. Long-term cortisol measures predict Alzheimer disease risk. Neurology. 2017;88:371-8.

88. Schrijvers EM, Direk N, Koudstaal PJ, Kirschbaum C, Hofman A, Tiemeier H, et al. Associations of serum cortisol with cognitive function and dementia: the Rotterdam study. J Alzheimers Dis. 2011;25(4):671-7.

89. Byers AL, Yaffe K. Depression and risk of developing dementia. Nat Rev Neurol. 2011;7(6):323-31.

90. Ricci S, Fuso A, Ippoliti F, Businaro R. Stress-induced cytokines and neuronal dysfunction in Alzheimer's disease. J Alzheimers Dis. 2012;28(1):11-24.

91. Vilalta-Franch J, Lopez-Pousa S, Llinas-Regla J, Calvo-Perxas L, Merino-Aguado J, Garre-Olmo J. Depression subtypes and 5-year risk of dementia and Alzheimer disease in patients aged 70 years. Int J Geriatr Psychiatry. 2013;28(4):341-50.

92. Wu KY, Lin KJ, Chen CH, Chen CS, Liu CY, Huang SY, et al. Diversity of neurodegenerative pathophysiology in nondemented patients with major depressive disorder: Evidence of cerebral amyloidosis and hippocampal atrophy. Brain Behav. 2018;8(7):e01016.

93. Proserpio P, Arnaldi D, Nobili F, Nobili L. Integrating sleep and Alzheimer's disease pathophysiology: hints for sleep disorders management. J Alzheimers Dis. 2018;63(3):871-86.

94. Shi L, Chen SJ, Ma MY, Bao YP, Han Y, Wang YM, et al. Sleep disturbances increase the risk of dementia: a systematic review and meta-analysis. Sleep Med Rev. 2018:40:4-16.

95. Traber MG, van der Vliet A, Reznick AZ, Cross CE. Tobacco-related diseases. Is there a role for antioxidant micronutrient supplementation? Clin Chest Med. 2000;21(1):173-87 x.

96. Durazzo TC, Mattsson N, Weiner MW. Smoking and increased Alzheimer's disease risk: a review of potential mechanisms. Alzheimers Dement. 2014; 10(3 Suppl):S122-45

97. Cataldo JK, Prochaska JJ, Glantz SA. Cigarette smoking is a risk factor for Alzheimer's disease: an analysis controlling for tobacco industry affiliation. J Alzheimers Dis. 2010;19(2):465-80.
98. Xu W, Yu JT, Tan MS, Tan L. Cognitive reserve and Alzheimer's disease. Mol Neurobiol. 2015;51(1):187-208.

99. Tucker AM, Stern Y. Cognitive reserve in aging. Curr Alzheimer Res. 2011; 8(4):354-60.

100. Stern Y, Gurland B, Tatemichi TK, Tang MX, Wilder D, Mayeux R. Influence of education and occupation on the incidence of Alzheimer's disease. Jama. 1994;271(13):1004-10.

101. Scarmeas N, Levy G, Tang MX, Manly J, Stern Y. Influence of leisure activity on the incidence of Alzheimer's disease. Neurology. 2001;57(12):2236-42.

102. Hamer M, Chida Y. Physical activity and risk of neurodegenerative disease: a systematic review of prospective evidence. Psychol Med. 2009;39(1):3-11.

103. Mendiola-Precoma J, Berumen LC, Padilla K, Garcia-Alcocer G. Therapies for prevention and treatment of Alzheimer's disease. Biomed Res Int. 2016;2016: 2589276.

104. Paillard T, Rolland Y, de Souto Barreto P. Protective effects of physical exercise in Alzheimer's disease and Parkinson's disease: a narrative review. J Clin Neurol. 2015;11(3):212-9.

105. Huang EJ, Reichardt LF. Neurotrophins: roles in neuronal development and function*. Annu Rev Neurosci. 2001;24:677-736.

106. de Wilde MC, Vellas B, Girault E, Yavuz AC, Sijben JW. Lower brain and blood nutrient status in Alzheimer's disease: Results from meta-analyses. Alzheimers Dement (N Y). 2017:3:416-31.

107. Scarmeas N, Stern Y, Mayeux R, Manly JJ, Schupf N, Luchsinger JA. Mediterranean diet and mild cognitive impairment. Arch Neurol. 2009; 66(2):216-25.

108. Smith PJ, Blumenthal JA. Diet and Neurocognition: review of evidence and methodological considerations. Curr Aging Sci. 2010;3(1):57-66.

109. van Wijk N, Broersen LM, de Wilde MC, Hageman RJ, Groenendijk M, Sijben JW, et al. Targeting synaptic dysfunction in Alzheimer's disease by administering a specific nutrient combination. J Alzheimers Dis. 2014;38(3):459-79.

110. Olivera-Pueyo J, Pelegrin-Valero C. Dietary supplements for cognitive impairment. Actas Esp Psiquiatr. 2017:45(Supplement):37-47.

111. Fraga VG, Carvalho MDG, Caramelli P, de Sousa LP, Gomes KB. Resolution of inflammation, n-3 fatty acid supplementation and Alzheimer disease: a narrative review. J Neuroimmunol. 2017;310:111-9.

112. Knekt P, Saaksjarvi K, Jarvinen R, Marniemi J, Mannisto S, Kanerva N, et al. Serum 25-hydroxyvitamin d concentration and risk of dementia. Epidemiology. 2014:25(6):799-804.

113. Shen L, Ji HF. Vitamin D deficiency is associated with increased risk of Alzheimer's disease and dementia: evidence from meta-analysis. Nutr J. 2015;14:76.

114. Licher S, de Bruijn R, Wolters FJ, Zillikens MC, Ikram MA, Ikram MK. Vitamin D and the risk of dementia: the Rotterdam study. J Alzheimers Dis. 2017;60(3):989-97.

115. Landel V, Annweiler C, Millet P, Morello M, Féron F. Vitamin D, Cognition and Alzheimer's Disease: The Therapeutic Benefit is in the D-Tails. J Alzheimers Dis. 2016;53:419-44.

116. Grimm MOW, Thiel A, Lauer AA, Winkler J, Lehmann J, Regner $L$, et al. Vitamin $D$ and Its Analogues Decrease Amyloid- $\beta$ (A $\beta$ ) Formation and Increase Aß-Degradation. Int J Mol Sci. 2017;18(12):2764.

117. Briones TL, Darwish H. Vitamin D mitigates age-related cognitive decline through the modulation of pro-inflammatory state and decrease in amyloid burden. J Neuroinflammation. 2012;9:244.

118. Mizwicki MT, Menegaz D, Zhang J, Barrientos-Duran A, Tse S, Cashman JR, et al. Genomic and nongenomic signaling induced by 1alpha,25(OH)2vitamin D3 promotes the recovery of amyloid-beta phagocytosis by Alzheimer's disease macrophages. J Alzheimers Dis. 2012;29(1):51-62.

119. Masoumi A, Goldenson B, Ghirmai S, Avagyan H, Zaghi J, Abel K, et al. 1alpha,25-dihydroxyvitamin D3 interacts with curcuminoids to stimulate amyloid-beta clearance by macrophages of Alzheimer's disease patients. J Alzheimers Dis. 2009:17(3):703-17.

120. Gezen-Ak D, Dursun E, Bilgic B, Hanagasi $H$, Ertan T, Gurvit $H$, et al. Vitamin D receptor gene haplotype is associated with late-onset Alzheimer's disease. Tohoku J Exp Med. 2012;228(3):189-96.

121. Annweiler C, Herrmann FR, Fantino B, Brugg B, Beauchet O. Effectiveness of the combination of memantine plus vitamin $D$ on cognition in patients with Alzheimer disease: a pre-post pilot study. Cogn Behav Neurol. 2012;25(3):121-7.

122. Annweiler C, Rolland Y, Schott AM, Blain H, Vellas B, Herrmann FR, et al. Higher vitamin $D$ dietary intake is associated with lower risk of alzheimer's disease: a 7-year follow-up. J Gerontol A Biol Sci Med Sci. 2012;67(11):1205-11.

123. Stein MS, Scherer SC, Ladd KS, Harrison LC. A randomized controlled trial of high-dose vitamin D2 followed by intranasal insulin in Alzheimer's disease. J Alzheimers Dis. 2011;26(3):477-84. 
124. Miller BJ, Whisner CM, Johnston CS. Vitamin D supplementation appears to increase plasma Abeta40 in vitamin D insufficient older adults: a pilot randomized controlled trial. J Alzheimers Dis. 2016;52(3):843-7.

125. Li R, Cui J, Shen Y. Brain sex matters: estrogen in cognition and Alzheimer's disease. Mol Cell Endocrinol. 2014;389(0):13-21.

126. Zárate S, Stevnsner T, Gredilla R. Role of Estrogen and Other Sex Hormones in Brain Aging. Neuroprotection and DNA Repair. Front Aging Neurosci. 2017;9:430.

127. Depypere H, Vierin A, Weyers S, Sieben A. Alzheimer's disease, apolipoprotein E and hormone replacement therapy. Maturitas. 2016;94:98-105.

128. Brinton RD. Investigative models for determining hormone therapy-induced outcomes in brain: evidence in support of a healthy cell bias of estrogen action. Ann N Y Acad Sci. 2005;1052:57-74.

129. Dye RV, Miller KJ, Singer EJ, Levine AJ. Hormone replacement therapy and risk for neurodegenerative diseases. Int J Alzheimers Dis. 2012;2012:258454

130. Imtiaz B, Taipale H, Tanskanen A, Tiihonen M, Kivipelto M, Heikkinen AM, et al. Risk of Alzheimer's disease among users of postmenopausal hormone therapy: a nationwide case-control study. Maturitas. 2017;98:7-13.

131. Shumaker SA, Legault C, Rapp SR, Thal L, Wallace RB, Ockene JK, et al. Estrogen plus progestin and the incidence of dementia and mild cognitive impairment in postmenopausal women: the Women's Health Initiative memory study: a randomized controlled trial. Jama. 2003;289(20):2651-62.

132. Wharton W, Baker LD, Gleason CE, Dowling M, Barnet JH, Johnson S, et al. Short-term hormone therapy with transdermal estradiol improves cognition for postmenopausal women with Alzheimer's disease: results of a randomized controlled trial. J Alzheimers Dis. 2011;26(3):495-505.

133. Henderson WW, Benke KS, Green RC, Cupples LA, Farrer LA. Postmenopausal hormone therapy and Alzheimer's disease risk: interaction with age. J Neurol Neurosurg Psychiatry. 2005;76(1):103-5.

134. Espeland MA, Rapp SR, Manson JE, Goveas JS, Shumaker SA, Hayden KM, et al. Long-term effects on cognitive trajectories of postmenopausa hormone therapy in two age groups. J Gerontol A Biol Sci Med Sci. 2017;72(6):838-45.

135. Fox M, Berzuini C, Knapp LA. Cumulative estrogen exposure, number of menstrual cycles, and Alzheimer's risk in a cohort of British women. Psychoneuroendocrinology. 2013;38(12):2973-82.

136. Marjoribanks J, Farquhar C, Roberts H, Lethaby A, Lee J. Long-term hormone therapy for perimenopausal and postmenopausal women. Cochrane Database Syst Rev. 2017;1:Cd004143.

137. Mattei TA. Is it all about contact? Neurodegeneration as a "protein freeze tag game" inside the central nervous system. Front Neurol. 2013;4:75.

138. Warren JD, Fletcher PD, Golden HL. The paradox of syndromic diversity in Alzheimer disease. Nat Rev Neurol. 2012;8(8):451-64.

139. Johnson SC, Koscik RL, Jonaitis EM, Clark LR, Mueller KD, Berman SE, et al. The Wisconsin registry for Alzheimer's prevention: a review of findings and current directions. Alzheimers Dement (Amst). 2018;10:130-42.

Ready to submit your research? Choose BMC and benefit from:

- fast, convenient online submission

- thorough peer review by experienced researchers in your field

- rapid publication on acceptance

- support for research data, including large and complex data types

- gold Open Access which fosters wider collaboration and increased citations

- maximum visibility for your research: over $100 \mathrm{M}$ website views per year

At $\mathrm{BMC}$, research is always in progress.

Learn more biomedcentral.com/submissions 